\title{
Successful emergency department thoracotomy for traumatic cardiac rupture: effective utilization of a fret sternum saw
}

\author{
Tsukasa Nakamura, M.D.,, ${ }^{1,2}$ Koji Masuda, M.D., ${ }^{2}$ Eiji Hitomi, M.D., ${ }^{3}$ \\ Yoshio Osaka, M.D., ${ }^{2}$ Toshimasa Nakao, M.D., ${ }^{1}$ Norio Yoshimura, M.D. ${ }^{1}$
}

${ }^{1}$ Department of Organ Transplantation and General Surgery, Kyoto Prefectural University of Medicine, Kyoto, Japan

Departments of ${ }^{2}$ Surgery, and ${ }^{3}$ Anesthesiology, Omihachiman Community Medical Center, Shiga, Japan

\begin{abstract}
Mortality following blunt chest injury and cardiac rupture remains high despite advances in the care of traumatic injuries. Indeed, most patients succumb to these injuries even prior to reaching a hospital. However, timely recognition and surgical intervention can save lives. We present the case of a 40-year-old woman who presented to our emergency department in cardiac arrest due to rupture of her left atrium following a major motor vehicle collision. The patient underwent emergency department thoracotomy with successful repair of the cardiac rupture. Emergency department thoracotomy, when indicated and performed by trained surgeons, can be the only lifesaving procedure available. Rapid median sternotomy using a cost-effective fret sternum saw does not require significantly more time than a left lateral thoracotomy or clamshell incision in an emergency situation. It can be an effective and alternative method of thoracic entry in the emergency department. Prognosis of cardiac rupture depends largely on the mechanism of injury, location of injury, signs of life: vital signs, and availability of timely intervention. When indicated, hesitation should be avoided. Expedient cardiac exposure is essential and leads to better results with improved survival rates in patients with blunt cardiac rupture.
\end{abstract}

Key words: Blunt trauma; cardiac rupture; cardiac tamponade; emergency department thoracotomy; fret sternum saw.

\section{INTRODUCTION}

Cardiac rupture following blunt chest trauma is associated with a critically high mortality rate. It is true, however, that quick diagnosis and appropriate management can save lives. Among them, emergency department thoracotomy (EDT) remains the most challenging procedure. ${ }^{[1-3]}$ The application of, indications for, and advantages and disadvantages of EDT are often debated. This case highlights the importance of and complications seen with EDT in a typical medical center.

\section{CASE REPORT}

A previously healthy 40-year-old Japanese female involved in a motorcycle collision sustained a handle bar injury to her

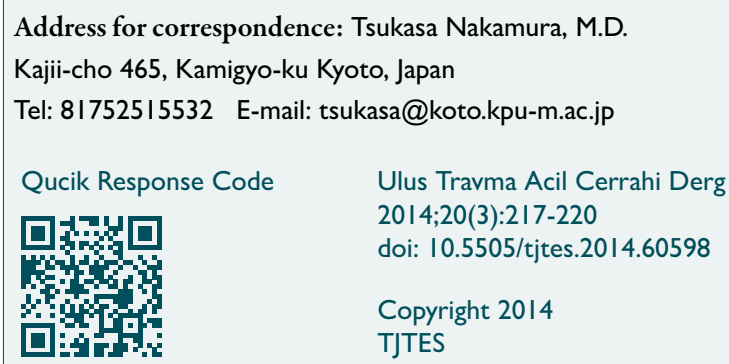

chest and a complex right talus fracture. Upon presentation to the ED, she was disoriented, with a heart rate $(H R)$ of 140 beats per minutes (bpm); her blood pressure was unmeasurable. Immediately, a primary survey and a focused assessment with sonography for trauma (FAST) were performed simultaneously. The FAST revealed significant pericardial fluid and cardiac tamponade. Within seconds, she decompensated into a brady-arrhythmia, followed by cardiac arrest. Pericardiocentesis was subsequently performed using a I2Fr drainage tube, and she was intubated. Blood spouted from the drainage tube, and her HR immediately rose to I40 bpm; however, her blood pressure remained significantly low. Her Glasgow Coma Scale (GCS), Injury Severity Score (ISS), Revised Trauma Score (RTS), and her probability of survival from the Trauma and Injury Severity Score (TRISS) were 3, $45,0.733$, and $2.6 \%$, respectively.

After the patient had been in the ED for 20 minutes (min), the decision was made to perform surgical closure of the cardiac rupture in the ED, because she had lost her vital signs due to hemorrhagic shock following the pericardial drainage. A crash midline sternotomy was performed, followed by opening her pericardium, and $\mathrm{O}, \mathrm{Rh}(\mathrm{D})$ positive red cell concentrate (RCC) transfusion was begun simultaneously (Japanese $R h(D)$ positive accounts for $99.5 \%$ of the population). 


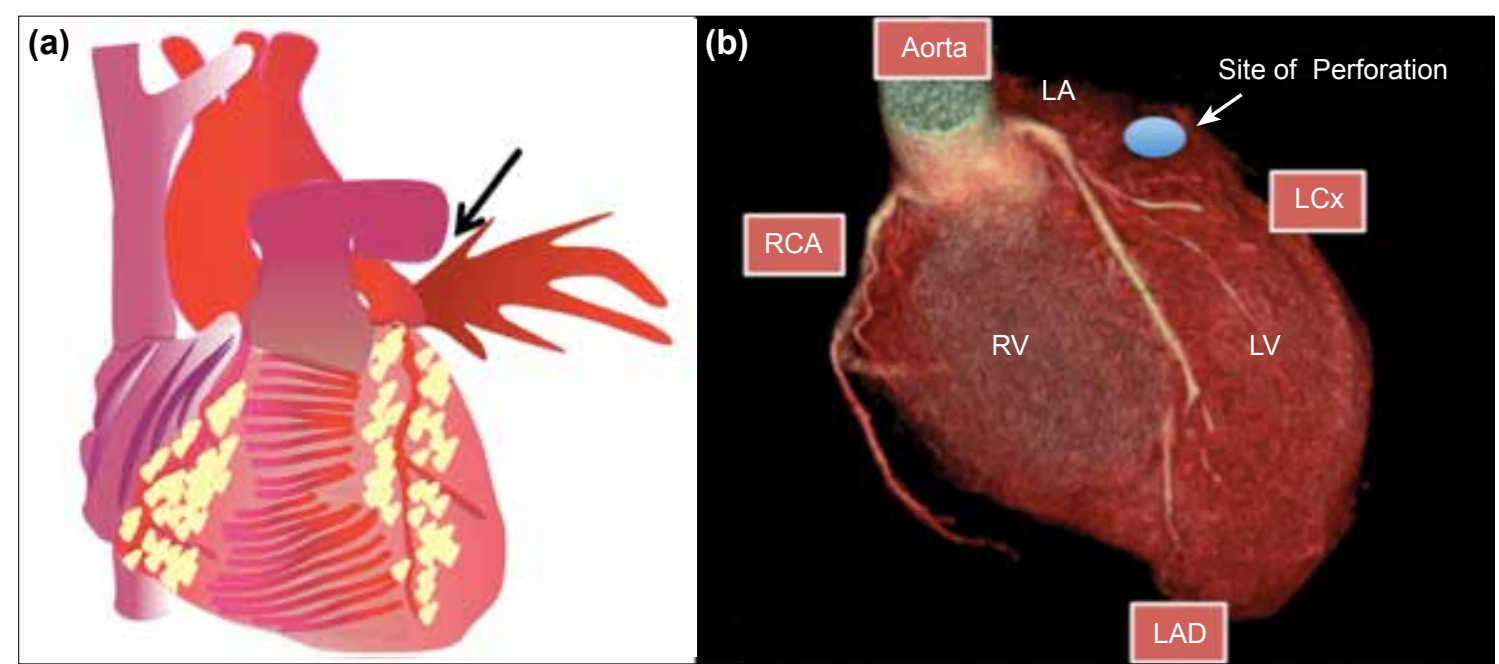

Figure 1. (a, b) The perforated site is indicated by the black and white arrows: the left atrium. (b) 3D cardiac CT was taken postoperatively.

A large amount of bleeding ensued and direct cardiac massage was initiated. Although the massive hemorrhage made detection of the perforation difficult, a left atrium rupture, measuring approximately $2-3 \mathrm{~cm}$, was identified by palpation (Fig. I).

The rupture was side-clamped with a Satinsky clamp. The perforation was closed with running 3-0 Prolene, and hemostasis was obtained. Disseminated intravascular coagulation (DIC) due to the massive hemorrhage manifested as bleeding from the endotracheal tube. Immediate simple wound closure and insertion of bilateral chest tubes were performed. Subsequently, the patient was transferred to the intensive care unit (ICU). Within 4 hours following the EDT, the patient's vital signs normalized and she recovered conscious-

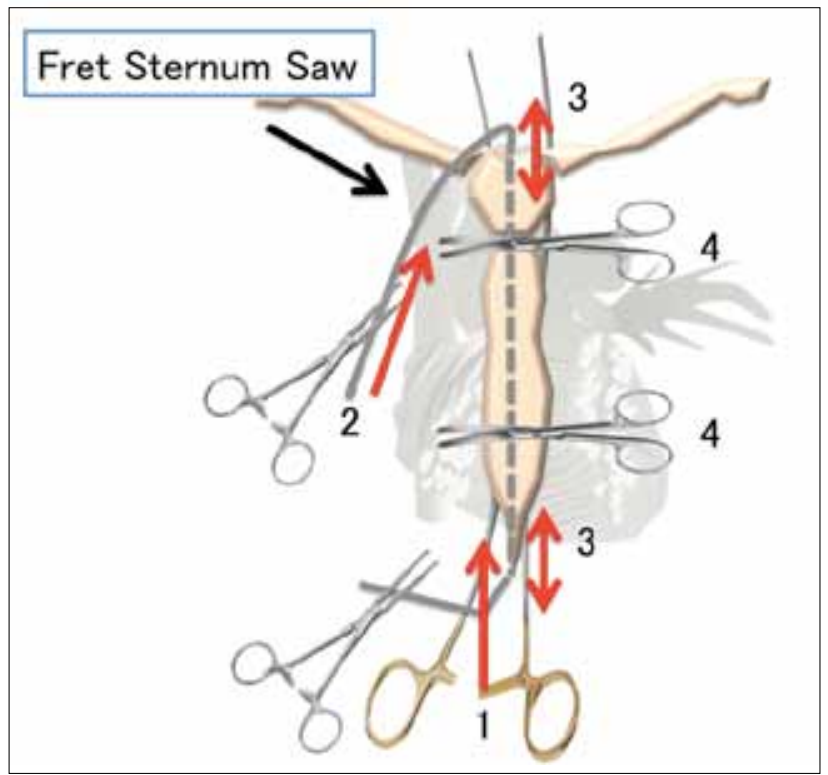

Figure 2. This figure illustrates the operation of a fret sternum saw. 1) A long forceps is inserted beneath the sternum. 2) The fret sternum saw is guided. 3) The sternum is divided. 4) Assistant surgeons place scissors on the sternum. ness. A total of $8400 \mathrm{ml}$ of RCC, $748 \mathrm{ml}$ of cell saver fluid, $6720 \mathrm{ml}$ of fresh frozen plasma (FFP), and 60 international units of platelets were transfused within the initial 24 hours, primarily based on the massive transfusion protocol. ${ }^{[4]} \mathrm{On}$ postoperative day 8 , after recovering from DIC, she underwent right talus fixation. Magnetic resonance imaging (MRI) of her brain revealed a left occipital lobe infarction primarily due to the period of low blood pressure. Her clinical symptoms included visual impairment and a slight dysmnesia that improved after intensive rehabilitation. She was able to successfully perform her activities of daily living and thus reenter society.

\section{DISCUSSION}

Cardiac rupture due to blunt chest trauma is seen rarely in the ED, as it is often fatal at the scene. Cardiac arrest prior to hospital presentation portends an extremely poor prognosis. Although survival rates of EDT in blunt chest trauma are very low, only $1.4 \%,{ }^{[3]}$ EDT can serve as the only lifesaving procedure available. Survival rates following EDT for blunt chest trauma strongly correlate with the mechanism of injury (MOI), location of major injury (LOMI), and signs of life (SOL). A more favorable prognosis is associated with isolated cardiac injury and the presence of SOL on arrival. ${ }^{\left[{ }^{[5]}\right.}$ Therefore, it is of vital importance to work quickly in order to decrease the mortality of cardiac rupture.

Initially, cardiac rupture following blunt chest trauma should be diagnosed by FAST, not computed tomography (CT) scan, as ultrasound is much faster and safer. ${ }^{[6]}$ Clinicians should be well aware that cardiac rupture can present with tamponade with or without intact pericardium or massive hemothorax..$^{[7]}$ Once the diagnosis is made, transfusion must begin as soon as possible. Due to the immediacy of the situation, type specific blood is not practical; thus, $O \operatorname{Rh}(D)$ negative packed red blood cells and AB FFP should be ready for immediate transfusion. ${ }^{\left[{ }^{8,9]}\right.}$ However, given the limited availability of this 
type of blood, an immediate call to the blood bank is crucial. Auto-transfusion should be considered early and set up prior to EDT. Physicians must consider autologous blood collection from a thoracostomy drainage tube or a pericardial window by means of a cell saver or blood preservation bag. This can compensate for a shortage in stored blood.

In this case, as our patient had lost vital signs, there was no time to transfer her to the operating theater. EDT was the only option. Generally, given adequate staff and equipment, EDT is recommended in cases where cardiac tamponade due to trauma is present and in which there is no adequate sustained response to pericardial drainage, ${ }^{[5,10]}$ mainly due to subsequent hemorrhagic shock. Median sternotomy, clamshell incision and left lateral thoracotomy are all techniques employed for cardiac exposure. However, a midline sternotomy can provide the best exposure of the heart, especially the superior mediastinal structures. Median sternotomy using a fret sternum saw, described below, does not require significantly more time than a left lateral thoracotomy or clamshell incision in an emergency situation. Needless to say, it is of vital importance to protect cerebral perfusion and prevent hypoxic damage in cases of cardiac arrest. Accordingly, the quickest approach to the heart is paramount in order to minimize hypoxic brain injury.

In cases of atrial cardiac rupture, it should be managed by application of a vascular clamp and oversewing the perforation. On the other hand, ventricular rupture can be managed with mattress suture technique by means of pledget reinforcements. ${ }^{\left[{ }^{I I]}\right.}$ In certain situations, it may prove difficult to identify the site of perforation or control bleeding by a direct clamping. In these situations, a short period of inflow interception accomplished by clamping of the superior (SVC) and inferior vena cava (IVC) may be effective. Furthermore, surgeons should not hesitate to set up cardiopulmonary bypass, if necessary and readily available.

Cardiopulmonary bypass and clamping of the SVC, IVC and aorta in order to maintain cerebral perfusion might also prevent huge air embolism in cases of large left atrium or ventricle rupture while suturing. Given this additional advantage, a median sternotomy is the recommended approach as it allows easy access to the great vessels.

It has been argued that an electric sternum saw is too expensive to be equipped in the ED. Our questionnaire survey of Japanese tertiary emergency medical centers revealed that less than $5 \%$ of the emergency centers were equipped with an electric sternum saw. The main reason was its high cost, which far outdistanced the other reasons cited, such as "unnecessary" or "non-frequent usage". This problem due to the price can be addressed with the application of the inexpensive and disposable fret sternum saw. This simple and quick method is often used in multiple organ procurement in the United Kingdom and other countries after donor brain or donor cardiac death (DBD or DCD). Application of this saw is described in Figure 2.

Instruments required for rapid thoracic entry and cardiac exposure are the fret sternum saw, a forceps longer than the sternum and two Kocher clamps. An assistant surgeon should be attentive to keeping the saw from leaping up, by means of holding copper scissors on the sternum (Fig. 2). Clearly, it is not difficult to install these instruments in a typical medical center in terms of the cost. We thus feel it is important for ED staff to be familiar with this method.

In conclusion, in cases of severe cardiac tamponade, EDT is the only life-saving option. The ED staff must be properly trained in order for EDT to be successful. As EDT is a struggle against time, decisions must be made quickly and without hesitation based upon the proper indications. We propose our sternotomy methods to make possible a swift thoracic entry. When managed appropriately, this will lead to improved outcomes in patients with cardiac rupture.

Ethical approval: Written informed consent was obtained from the patient for publication of this case report and the accompanying images. A copy of the written consent is available for review by the Editor-in-Chief of this journal upon request.

\section{Conflict of interest: None declared.}

\section{REFERENCES}

1. Baker CC, Thomas AN, Trunkey DD. The role of emergency room thoracotomy in trauma. J Trauma 1980;20:848-55.

2. Moreno C, Moore EE, Majure JA, Hopeman AR. Pericardial tamponade: a critical determinant for survival following penetrating cardiac wounds. J Trauma 1986;26:821-5.

3. Cothren CC, Moore EE. Emergency department thoracotomy for the critically injured patient: Objectives, indications, and outcomes. World J Emerg Surg 2006;1:4.

4. Elmer J, Wilcox SR, Raja AS. Massive transfusion in traumatic shock. J Emerg Med 2013;44:829-38.

5. Rhee PM, Acosta J, Bridgeman A, Wang D, Jordan M, Rich N. Survival after emergency department thoracotomy: review of published data from the past 25 years. J Am Coll Surg 2000;190:288-98.

6. Plummer D. Principles of emergency ultrasound and echocardiography. Ann Emerg Med 1989;18:1291-7.

7. Powell MA, Lucente FC. Diagnosis and treatment of blunt cardiac rupture. WV Med J.1997;93:64-7.

8. Berséus O, Boman K, Nessen SC, Westerberg LA. Risks of hemolysis due to anti-A and anti-B caused by the transfusion of blood or blood components containing ABO-incompatible plasma. Transfusion 2013;53 Suppl 1:114-23.

9. Khan S, Allard S, Weaver A, Barber C, Davenport R, Brohi K. A major haemorrhage protocol improves the delivery of blood component therapy and reduces waste in trauma massive transfusion. Injury 2013;44:587-92.

10. Nan YY, Lu MS, Liu KS, Huang YK, Tsai FC, Chu JJ, et at. Blunt traumatic cardiac rupture: therapeutic options and outcomes. Injury 2009;40:938-45.

11. Williams JB, Silver DG, Laws HL. Successful management of heart rupture from blunt trauma. J Trauma 1981;21:534-7. 


\section{OLGU SUNUMU - ÖZET}

\section{Travmatik kardiyak rüptür için başarılı acil servis torakotomisi:}

\section{Fret sternum testeresinin efektif kullanımı}

Dr. Tsukasa Nakamura, ${ }^{1,2}$ Dr. Koji Masuda, ${ }^{2}$ Dr. Eiji Hitomi, ${ }^{3}$ Dr. Yoshio Osaka, ${ }^{2}$ Dr. Toshimasa Nakao, ${ }^{1}$ Dr. Norio Yoshimura ${ }^{1}$

${ }^{1}$ Kyoto İdari Üniversitesi Tıp Fakültesi, Transplantasyon ve Rejeneratif Cerrahi Anabilim Dalı, Kyoto, Japonya;

Omihachiman Toplum Sağlığı Merkezi, ${ }^{2}$ Cerrahi ve ${ }^{2}$ Anesteziyoloji Bölümü, Shiga, Japonya

Travmatik yaralanmaların bakımında ilerlemelere rağmen künt göğüs travması ve kardiyak rüptür sonrası mortalite oranları yüksek düzeydedir. Gerçekten, hastaların çoğu bir hastaneye varmadan önce ölmektedir. Ancak zamanında farkına varma ve cerrahi girişim yaşamları kurtarabilmektedir. Büyük bir motorlu taşıt çarpmasıyla oluşan sol atriyum rüptürü sonucu acil servisimize kardiyak arrest ile getirilen 40 yaşındaki bir kadın olgu sunuldu. Hasta acil serviste torakotomi ve başarılı bir kardiyak rüptür onarımı geçirdi. Gerekli olduğunda ve eğitimli cerrahlar tarafından gerçekleştirildiğinde acil serviste yapılan torakotomi mevcut tek yaşam kurtarııı işlem olabilir. Maliyet-etkinlikli Fret sternum testeresi kullanılarak hızı bir median sternotomi acil durumda yapılan sol lateral torakotomi veya istiridye kabuğu tarzında kesiye göre anlamlı derecede daha fazla zamana gerek duyulmadan yapılabilir. Acil serviste toraksa girişin etkili alternatif bir yöntemidir. Kardiyak rüptürün prognozu geniş ölçüde travmanın mekanizması, yeri, yaşam belirtileri, yaşamsal bulgular ve zamanında müdahale olanaklarının varlığına bağlıdır. Gerekli olduğunda bir an duraklanmamalıdır. Kalbin hızlı açınımı esastır. Hızlı girişim, künt kardiyak rüptürü olan hastalarda iyileşmiş sağkalım oranlarıyla daha iyi sonuçların alınmasına yol açar. Anahtar sözcükler: Acil servis; Fret sternum testeresi; kardiyak rüptür; kardiyak tamponat; künt travma.

Ulus Travma Acil Cerrahi Derg 2014;20(3):217-220 doi: 10.5505/tjtes.2014.60598 